DORIS LESSING 
This page intentionally left blank 


\title{
Doris Lessing
}

\section{Sufi Equilibrium and the Form of the Novel}

\author{
Shadia S. Fahim
}

Lecturer in English Literature and Language

Ain-Shams University, Cairo

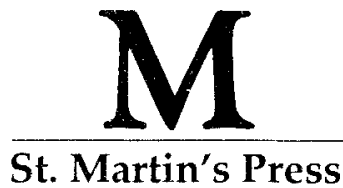


All rights reserved. No reproduction, copy or transmission of this publication may be made without written permission.

No paragraph of this publication may be reproduced, copied or transmitted save with written permission or in accordance with the provisions of the Copyright, Designs and Patents Act 1988, or under the terms of any licence permitting limited copying issued by the Copyright Licensing Agency, 90 Tottenham Court Road, London W1P 9HE.

Any person who does any unauthorised act in relation to this publication may be liable to criminal prosecution and civil claims for damages.

First published in Great Britain 1994 by THE MACMILLAN PRESS LTD

Houndmills, Basingstoke, Hampshire RG21 2XS and London

Companies and representatives throughout the world

A catalogue record for this book is available from the British Library.

DOI $10.1057 / 9780230375222$

First published in the United States of America 1994 by Scholarly and Reference Division,

ST. MARTIN'S PRESS, INC., 175 Fifth Avenue, New York, N.Y. 10010

ISBN 978-0-312-10293-7

Library of Congress Cataloging-in-Publication Data Fahim, Shadia S.

Doris Lessing : Sufi equilibrium and the form of the novel / Shadia S. Fahim.

p. $\mathrm{cm}$.

Includes bibliographical references (p. ) and index.

ISBN 978-0-312-10293-7

1. Lessing, Doris May, 1919- Criticism and interpretation.

2. Sufi literature-History and criticism. 3. Sufism in literature.

4. Fiction-Technique. 5. Literary form. I. Title.

PR6023.E833Z64 1994

$823 \cdot .914-\mathrm{dc} 20$ 
To my husband and children, Amir and Engy 
This page intentionally left blank 


\section{Contents}

Preface

viii

Acknowledgements

$x$

Introduction

1 The Grass is Singing

2 The Golden Notebook

3 The Memoirs of a Survivor

85

4 The Science Fiction Series

136

5 Conclusion

235

Notes

Select Bibliography

269

Index

277 


\section{Preface}

Doris Lessing was acknowledged from the very beginning as a novelist in the tradition of Classical Realism; hence the surprise of critics at her development towards mysticism and forms of science fiction which verge on myth and Oriental fables. The purpose of this study is to examine the rationale of this development and to consider the unifying motifs, which provide a coherent shape to her artistic vision in her consistent search for equilibrium. This study will follow Lessing's development from her early realistic writing to her later science fiction series - a period of over thirty years which encompass the most dramatic changes in her writing career.

The introductory section aims at examining the aesthetic theories as well as the ideological and philosophical influences that have contributed to Lessing's development, in order to establish a theoretical framework for the study and to stipulate the key motifs studied thereafter. The division into the four chapters marks the significant phases of Lessing's development. The four novels selected represent significant stages in Lessing's work, covering the period from 1950 to the year 1983, which marked the completion of her science fiction series.

Chapter 1 focuses on The Crass is Singing, which represents the author's early traditionally realistic writing, in order to evaluate the achievement of that first novel which proves to be more complex than is usually supposed. My analysis of this novel will show how far the preoccupations of Lessing's later novels find expression in this early work to establish a point of reference for her later development.

Chapter 2 studies The Golden Notebook, which marks a turningpoint in formal structure in Lessing's canon and is selected as evidence of her interest in Sufism at that early stage. Critics frequently refer to The Four-Gated City in 1969 as the starting point of Lessing's interest in Sufi methods of thought. I contend that such interest is evident since The Golden Notebook in 1962 and that it is crucial in understanding the complexity of the inner action and sheds light on the statement it makes through the form.

Chapter 3 concentrates on the study of The Mentoirs of a Survivor, which has elicited a comparatively limited amount of criticisin 
but which proves to be a major achievement. The Memoirs of a Survivor epitomizes the quest for equilibrium and raises the issue of reconciling two apparently incompatible universes - the realistic and the fantastic. This issue becomes problematic in the terms of literary criticism but reveals further significance when brought into line with Sufi methods of writing. Sources from Sufi theories of literature will serve as points of reference in my analysis of that domain to set a polemic against a widespread misunderstanding of the novel.

Chapter 4 considers Lessing's science fiction series, 'Canopus in Argos', with special reference to the first volume, Re: Colonized Planet 5 Shikasta. In this chapter, the relevance of the science fiction genre to the theme of equilibrium is studied in the light of the talewithin-tale technique of the oriental fables, since the series derive its title from Bidpai's fables The Lights of Canopus. Later on in the chapter I concentrate on Shikasta, in order to illustrate how the theme of equilibrium develops in relation to the narrative technique. This involves the reader's activity in reading and signifies the author's development towards more modern modes of writing.

This study charts and discusses Doris Lessing's development in the context of Eastern as well as Western modes that have influenced her work, since the interaction between the two is illuminating in understanding her ceuvre and helps to explain many areas of misunderstanding in her canon. 


\section{Acknowledgements}

The author and publishers are grateful to the following for permission to quote copyright material: Excerpts from The Grass is Singing $(\mathcal{C}$ Doris Lessing 1950, 1978 are reprinted by kind permission of HarperCollins Publishers. Excerpts from Re: Colonised Planet 5 Shikasta (C) Doris Lessing 1979 are reprinted by kind permission of Jonathan Cape Ltd and Alfred A. Knopf, Inc. Excerpts from The Memoirs of a Survivor by Doris Lessing appear by kind permission from The Octagon Press Ltd, London. Excerpts from The Sufis by Idries Shah are reprinted by kind permission of The Octagon Press Ltd, London. Excerpts from Sufi Expressions of the Mystic Quest by Laleh Bakhtiar are reprinted by kind permission of Thames and Hudson Ltd. Excerpts from The Golden Notebook (C) Doris Lessing 1962, and The Grass is Singing (C) Doris Lessing 1950 are reproduced by kind permission of Michael Joseph Ltd and Simon \& Schuster Ltd. 